\title{
Contributions to the Evolution of Blood Pressure Regulation
}

\author{
Part I: The Effect of Biogenic Amines and Nicotine on the Blood Pressure of Fish \\ By H. Schievelbein, Rosmarie Vogel and W. Lorenz, with the assistance of A. Schmal \\ From the Institut für Klinische Chemie und Klinische Biochemie der Universität München \\ (Direletor: Prof. Dr. Dr. E. Werle)
}

(Eingegangen am 9. Mai 1969)

\begin{abstract}
The intravenous injection of adrenaline and noradrenaline induces a dose-dependent increase of blood pressure in cartilagenous and teleost fish. Compared to the effect of catecholamines in dogs, the fish react much more slowly and only to higher doses. From the inhibition of adrenal secretion by the $\alpha$-receptor-blocker regitin and the release of endogenous pressor substances by nicotine, it can be concluded that adrenergic circulation control is operative in fishes. Especially in cartilagenous fish, histamine, acetylcholine and serotonin cause irregular depressor effects and only in relatively high doses similar to those found in mammals.
\end{abstract}

Die intravenöse Injektion von Adrenalin und Noradrenalin führt bei Knorpel- und Knochenfischen (Katzenhai und Wels) zu einer dosisabhängigen Blutdrucksteigerung, welche im Vergleich zu derjenigen des Hundes einen geringeren Dosiswirkungsgrad und eine verzögerte Reaktion aufweist. Die Hemmung von adrenergen Sekretionsmechanismen durch den $\alpha$-Rezeptorblocker Regitin und die Freisetzung von endogenen pressorischen Substanzen durch Nikotin führen zu dem Schluß des Vorbandenseins adrenerger Blutdruckregulation. Histamin, Acetylcholin und Serotonin führen vornehmlich in Knorpelfischen erst in sehr hoher Dosierung und auch nicht regelmäßig zu der typischen, bei Mammalia beobachteten Wirkung.

As far as the nerval and humoral control of cardiovascular system of mammals is concerned, at least two different principles exist: neuronal secretion mechanisms e. $g$. the adrenergic system and the enzymic release of vasoactive polypeptides (e. g. the kallikrein-kinin system or the renin-angiotensin system). Besides adrenaline or noradrenaline, other biogenic amines, e. g. 5-hydroxytryptamine (serotonin) or histamine, affect the blood pressure of mammals. It is not known, whether the latter amines are causatively connected with blood pressure regulation in mammals, but some of them are supposed to control cardiovascular tonus in lower animals, p.e. serotonin is supposed to regulate the action of the heart of the mussel Venus mercenaria (1).

We investigated the action of several vasoactive substances on the blood pressure of cartilagenous and teleost fish in order to show, whether the systems mentioned above exist in lower orders of vertebrates.

\section{Methods and materials}

Cat sharks (Scyliorbinus stellaris) with body weights from 400 to $600 \mathrm{~g}$ were used as representatives of the chondrichthyes, and catfishes (Silurus glanis), weight ranging from 1,300 to $4,000 \mathrm{~g}$, as representatives of the teleosts.

The animals were anaesthetized by injection of urethane $(20 \%$ solution, average volume $6 \mathrm{~m} / / \mathrm{kg}$ ) in three portions into the muscles of the tail. The onset of imbalance was taken as an indication of a sufficient degree of anaesthesia.

The fish were kept in a normal position in a polyethylene basin by a loose turn of a gauze bandage, which was knotted behind the pectoral fin. The basin was placed in a bigger one so that $2 / 3$ of the fish's body was under the water surface, with the tail fixed outside the basin. The oxygen supply was secured by irrigation of the basin with water in the vicinity of the head (shark: seawater $20^{\circ} \mathrm{C}$, catfish: tap water $10^{\circ} \mathrm{C}$ ).

The tail was cut off with a sharp blade just before the tail fin, then, without further preparation, polyethylene canulas were inserted into the caudal artery for measurement of the blood pressure and into the caudal vein for the application of drugs.

Measuring instruments: arterial blood pressure - Statham Strain gage transducer P $23 \mathrm{Db}$; amplifier - Hellige electromanometer Ma-88; recording instrument - Hellige Multi-PenRecorder B-1. The electromanometer was adjusted to maximal sensitivity independent of the actual blood pressure so that changes in pressure of $1 \mathrm{~mm} \mathrm{Hg}$ could be recorded.

Substances and drugs used: acetylcholine (Roche), adrenaline (Suprarenin Hoechst), histamine (Imido, Roche), nicotine (commercial product, distilled under nitrogen), noradrenaline (Arterenol, noradrenaline hydrochloride Hoechst), regitin (2-(N-pTolyl-N - $m$-hydroxyphenyl - aminomethyl)-imidazoline-hydrochloride, Ciba), serotonin (5-hydroxytryptamine, Fluka).

\section{Results}

The actual systolic blood pressure in the shark ranged from 8 to $17 \mathrm{mmHg}$. There seems to be a relationship between body weight and/or age and the blood pressure, e. g. a catfish weighing $1,370 \mathrm{~g}$ (age $1 / 2$ year approximatively) had a blood pressure of $19 \mathrm{mmHg}$ and another weighing $4,000 \mathrm{~g}$ (age $31 / 2$ years approximatively) was found to have a blood pressure of $95 \mathrm{mmHg}$. Diminution of the oxygen tension lowered the blood pressure in all fishes.

The injection of adrenaline led to a dose-dependent rise in blood pressure (Fig. 1). The doses needed are much higher as in mammals. On the basis of these findings, it was of interest to compare the blood pressure effects in fishes and in mammals, taking dogs as their representatives. Values for dogs are derived from earlier papers from our research group. The comparison of the adrenaline-induced pressor response in sharks and dogs is given in figure 2 . Besides the much higher effective dose in fish, the time needed for the return to normal values is much longer. 


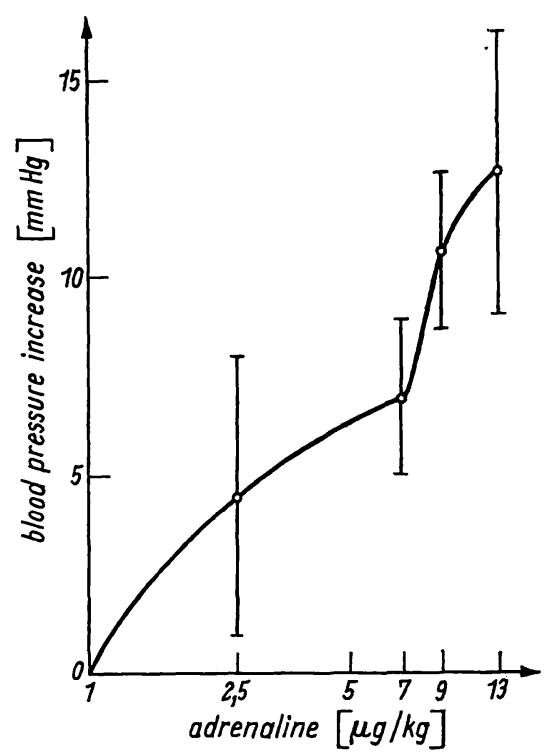

Fig. 1

Log/dose response curve for adrenaline and the cat shark blood pressure (means and standard deviation)

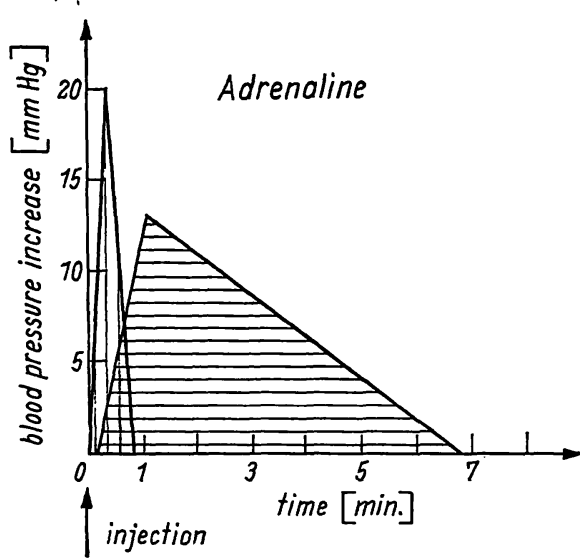

Fig. 2

Comparison of the adrenaline-induced pressor response in cat shark $(\equiv, 13 \mu \mathrm{g} / \mathrm{kg}, \mathrm{n}=3$ ), and $\operatorname{dog}(111,0.2 \mu \mathrm{g} / \mathrm{kg}, \mathrm{n}=5$ )

It is well known that adrenaline may produce a rise in blood pressure followed by a decrease for example in dogs or sometimes there may be only a decrease. In fishes we have never observed a decrease or a biphasic reaction after the injection of adrenaline. For the comparative interpretation of figure 2 only those dogs were used, in which adrenaline produced an increase.

The application of noradrenaline caused a rise in blood pressure, however not as high as that induced by equimolecular doses of adrenaline. Comparative values for noradrenaline-induced effects in fish and dog are shown in figure 3.

In the shark, the injection of bistamine (13 to $92 \mu \mathrm{g} / \mathrm{kg}$ ) sometimes resulted in a slight rise and sometimes in a slight decrease of the blood pressure, which did not exceed 2 or $3 \mathrm{mmHg}$.

The effect of histamine application was somewhat more pronounced in the catfish than in the shark, in one case a dose of $3.6 \mu \mathrm{g} / \mathrm{kg}$ led to a decrease of blood pressure by $3.5 \mathrm{mmHg}$, [see fig. 1 in VOGEL and coworkers (2)].

Acetylcholine $(4.9 \mu \mathrm{g} / \mathrm{kg}$ mean dose) lowered the blood pressure in catfish by $4 \mathrm{mmHg}$ (mean of four experi-

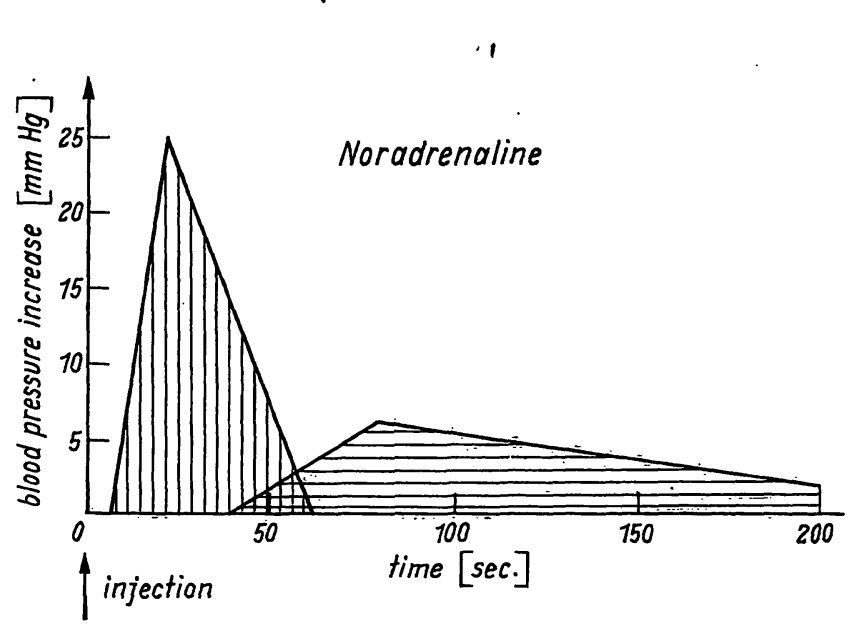

Fig. 3

Comparison of the noradrenaline-induced pressor response in cat shark ( $\equiv, 35 \mu \mathrm{g} / \mathrm{kg}, \mathrm{n}=5)$, and $\operatorname{dog}(|1|, 0.2 \mu \mathrm{g} / \mathrm{kg}, \mathrm{n}=7)$

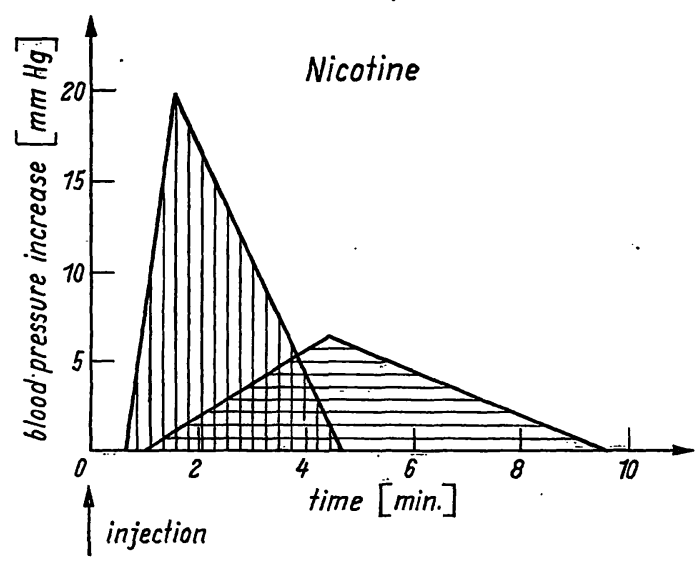

Fig. 4

Comparison of the nicotine-induced pressor response in cat shark (三, $26 \mu \mathrm{g} / \mathrm{kg}, \mathrm{n}=4$ ), and $\operatorname{dog}(I I \mid, 35 \mu \mathrm{g} / \mathrm{kg}, \mathrm{n}=14$ )

ments; see also figure 1 in VOGEL and coworkers (2)). Sharks were not investigated.

The injection of serotonin led to a decrease in blood pressure in shark and catfish, although compared to the response of mammals, enormous doses are needed, e. $g$. $90 \mu \mathrm{g} / \mathrm{kg}$ for a decrease of $3 \mathrm{mmHg}$.

In contrast to the response to adrenaline and noradrenaline, the effects of histamine and serotonin could only be produced irregularly and sometimes only with very high doses, so a physiological function for these amines in fish is very improbable. The response to the catecholamines can be considered as nearer the physiological range and therefore we tried to find evidence for endogenous catecholamine stores.

The injection of nicotine led to a rise in blood pressure and to stimulation of the respiration. Comparative interpretations for changes in circulation of cat shark and dog can be seen in figure 4 .

The response to adrenaline, noradrenaline and nicotine was blocked by pretreatment with regitin, e. g. $2 \mu \mathrm{g} / \mathrm{kg}$, whereas the respiratory response to nicotine was not influenced. In one case pretreatment with regitin caused a decrease of blood pressure after nicotine. 


\section{Discussion}

DoHRN and REIN in 1950 (3) found blood pressures of values of 12 to $25 \mathrm{mmHg}$ in sharks. These values observed in the Aorta ventralis are in good agreement with our findings in the caudal artery of sharks and catfish.

From our results, especially with regard to the dosedependent response to adrenaline and the effect of nicotine and regitin, which are similar to these in mammals, we assume that the adrenergic system is connected with blood pressure regulation in fishes.

It is noteworthy that the dose of adrenaline needed for a marked effect in the dog is much lower than in the fish. In contrast the doses of nicotine needed for indirect action (i. e. liberation of catecholamine from endogenous stores) is in the same order of magnitude as in the dog. This may be a consequence of physiological blood pressure regulation by a catecholamine derivative or analogue. This derivative may act in fish in doses comparable to those of adrenaline in mammals but may be released by nicotine in the same dose relationship as in the dog. With regard to the higher doses needed in fish to elicite a retarded response, compared with mammals, the anatomical structure may be at least partly responsible for this. The different structure of the vascular system (larger venous sinus) may be responsible for a slower transport rate. For detailed discussion see Voger and coworkers (2).

The lag period and the time of increase are much longer in catfish than in the shark. This may be a consequence of the greater body weight of the catfish used and factors similar to those suggested in the preceding. The tempesimilar to those suggested in the preceding paragraph. The temperature of the water under normal conditions may be also habe an influence on these retarded reactions.

There is no essential difference in the reaction to biogenic amines and the other substances used between cartilagenous and teleost fishes. This may be interpreted in favor of blood pressure regulation by adrenergic mechanism in all chordata, inasmuch as it is known that the vascular system of amphibia and birds are reactive to catecholamines too.

During the preparation of this paper we became aware of papers by Schwartz and Borzelleca $(4,5)$. These authors described experiments on the effect of some adrenergic drugs and adrenaline on the blood pressure in sharks. Their results are essentially the same results as described in this paper.

With regard to earlier investigations (6) and considering the results by SCHWARTZ and BorzelLECA who proved the existence of $\alpha$ - and $\beta$-receptors in sharks and the findings obtained by us, we conclude that adrenergic regulations have been proved to exist in teleost and cartilagenous fish.

These investigations were partly performed at the "Naples Zoological Station", and we are very grateful to Prof. Dr. E. Rocca and Dr. R. MARTIN for valuable advice.

We acknowledge financial support by the Deutsche Forschungsgemeinschaft.

\section{References}

1. ERSPAMER, V., in Handbuch der experimentellen Pharmakologie, Vol. XIX, p. 245. 5-Hydroxytryptamine and Related Indolealkylamines, Eds.: O. EICHLER and A. FARAH. Springer-Verlag, BerlinHeidelberg (1966). - 2. Vogei, R., H. SChIEVELbeIN; W. LoRENZ and E. Werle, this journal 7, 464 (1969). - 3. DoHrN, A. and F. H.
ReIn, Pubbl. Staz. Zool. Napoli 22, fasc. 2, 1 (1950). - 4. Schwartz, S. L. and J. F. Borzelleca, Toxicol. appl. Pharmacol. 12, 307 (1968) - 5. Schwartz, S. L. and J. F. BorzellecA, Science Washington 163, 395 (1969). - 6. Lutz, B. R. and L. C. WYMAN, Biol. Bull. Lancaster 62, 17 (1932).
Priv. Doz. Dr. H. Schievelbein 8000 München 15

Nussbaumstr. 20 